\title{
UPAYA PENGEMBANGAN OBYEK WISATA PASIR MERAH DI DESA OMBOLATA AFULU KABUPATEN NIAS UTARA
}

\author{
Yulius Gulo', Sugiharto² \\ 'Alumnus S1 Jurusan Pendidikan Geografi Fakultas Ilmu Sosial Universitas Negeri Medan \\ 2Jurusan Pendidikan Geografi Fakultas Ilmu Sosial Universitas Negeri Medan \\ Jl. Willem Iskandar Psr V Medan Estate Medan, 20211 Indonesia \\ Email:yuliusgulo@gmail.com
}

\begin{abstract}
Abstrak:
Penelitian ini bertujuan untuk mengetahui : (1) Keadaan prasarana dan sarana, (2) Penerapan sapta pesona, dan (3) upaya yang dilakukan oleh pemerintah daerah dan masyarakat setempat dalam mengembangkan obyek wisata Pasir Merah di Desa Ombolata Afulu. Penelitian ini dilakukan di Desa Ombolata Afulu pada tahun 2016. Populasi dalam penelitian ini adalah seluruh objek wisata Pasir Merah di Desa Ombolata Afulu, penentuan sampel dalam penelitian ini yaitu total sampling. Teknik pengumpulan data yang digunakan adalah teknik komunikasi langsung dan observasi. Teknik analisis data yang digunakan adalah deskriptif kualitatif. Hasil penelitian menunjukkan: (1) Keadaan prasarana kepariwisataan di objek wisata Pasir Merah Desa Ombolata Afulu yang meliputi jaringan jalan, jaringan listrik, jaringan telekomunikasi, air bersih dan pelayanan kesehatan tergolong sedang (skor 2,2). Keadaan sarana kepariwisataan di objek wisata Pasir Merah Desa Ombolata Afulu yakni transportasi, rumah makan, pondok pengunjung, penyediaan souvenir, tempat penginapan, promosi, obyek/atraksi wisata, pemandu wisata, tempat sampah, toilet dan tempat parkir tergolong buruk (skor 1,45). (2) Penerapan sapta pesona di objek wisata Pasir Merah Desa Ombolata Afulu yang mencakup keamanan, ketertiban, kebersihan, kesejukan, keindahan, keramah-tamahan dan kenangan tergolong sedang (skor 14). (3) Upaya pengembangan objek wisata Pasir Merah di Desa Ombolata Afulu dari pihak pemerintah antara lain membangun pondok dan menjalankan rutin kegiatan kelompok sadar wisata. Upaya pengembangan objek wisata Pasir Merah di Desa Ombolata Afulu dari pihak masyarakat yakni mendukung kegiatan pemerintah dan turut ikut serta dalam membangun penginapan dan rumah makan.
\end{abstract}

\section{Kata kunci : objek wisata, sapta pesona, pasir merah}

\section{PENDAHULUAN}

Pariwisata merupakan salah satu sektor jasa yang terus dikembangkan untuk memperbesar pendapatan negara dan memperluas kesempatan usaha serta lapangan kerja, mendorong kemajuan pembangunan daerah, sehingga tingkat kemakmuran dan kesejahteraan rakyat meningkat. Kegiatan kepariwisataan adalah sebuah kegiatan yang dilakukan untuk orang yang melakukan kegiatan perjalanan. Meskipun pengertian pariwisata bukan sebuah industri, tetapi kepariwisataan dapat memberikan kenaikan berkembangnya keragaman industri (Marpaung, 2002).
Perkembangan kepariwisataan saat ini demikian pesat dan merupakan fenomena global dengan melibatkan jutaan manusia baik di kalangan masyarakat industri pariwisata maupun penggunanya. Usaha individu untuk meningkatkan taraf kehidupan ekonominya menjadikan mereka berusaha untuk menciptakan lapangan kerja sendiri dengan memanfaatkan potensi yang dimiliki oleh dirinya sendiri dan potensi lain, seperti pariwisata. Kegiatan pariwisata dan obyek wisata di suatu daerah akan menyebabkan terciptanya lapangan kerja baru sehingga masyarakat dapat memanfaatkannya.

Pariwisata tidak lepas dari sektor lain terutama industri, khususnya industri 
kerajinan, aspek keamanan, aspek pendidikan, potensi wilayah dan lain-lain. Perkembangan dan pertumbuhan pariwisata perlu diantisipasi agar perkembangan tetap pada daya dukungnya. Penilaian perkembangan pariwisata suatu daerah juga

sangat penting guna menentukan prioritas dan strategi pengembangannya serta memproyeksikan kebutuhan sarana dan prasarana yang dibutuhkan sesuai dengan pertumbuhan dan perkembangan untuk masa yang akan datang.

Kepariwisataan di Indonesia ini sangat penting dan merupakan salah satu sektor penghasil devisa negara di luar minyak dan gas bumi. Pemerintah berusaha terus meningkatkan dan mengembangkan kepariwisataan guna meningkatkan serta menstabilkan perekonomian negara dalam rangka mewujudkan masyarakat adil dan makmur. Pembangunan kepariwisataan diarahkan pada peningkatan pariwisata menjadi sektor andalan yang mampu mengalahkan kegiatan ekonomi, termasuk sektor lain yang terkait sehingga lapangan kerja, pendapatan masyarakat, pendapatan asli daerah dan pendapatan negara, serta penerimaan negara meningkat melalui pembangunan dan pendayagunaan berbagai potensi kepariwisataan nasional (GBHN, 1993).

Sumatera Utara merupakan kota terbesar ketiga di Indonesia memiliki beragam tempat wisata yang menarik yang banyak dikunjungi oleh wisatawan. Selain dari pada itu Sumatera Utara juga merupakan sepuluh provinsi yang ditunjuk sebagai daerah wisata nasional disebabkan memiliki keanekaragaman hayati yang tinggi berupa sumber daya alam yang berlimpah, baik di darat maupun di perairan. Semua potensi tersebut mempunyai peranan penting bagi pengembangan kepariwisataan.

Pengembangan pariwisata di Sumatera Utara sebagai bagian integral dari pembangunan nasional yang telah dilaksanakan seperti halnya daerah-daerah lain. Walaupun pengembangan obyek wisata telah dilakukan, akan tetapi pengembangannya belum merata di setiap wilayah kabupaten. Hal ini tidak terlepas dari ketersediaan prasarana dan sarana kepariwisataan serta penerapan sapta pesona. Faktor-faktor pendorong pariwisata tersebut adakalanya tidak seluruhnya tersedia di suatu daerah tertentu sehingga menyebabkan pariwisata kurang berkembang.

Kabupaten Nias Utara merupakan salah satu kabupaten yang terbentuk berdasarkan Undang-Undang Nomor 45 Tahun 2008 tentang Pembentukan Kabupaten Nias Utara di Provinsi Sumatera Utara. Salah satu program pemerintah daerah Kabupaten Nias Utara saat ini yaitu memajukan sektor kepariwisataan sebagai salah satu sumber daya alam yang potensial untuk dikembangkan. Sektor kepariwisataan dianggap mampu memberi sumbangan pada penghasilan daerah dalam bentuk pajak maupun retribusi daerah. Potensi kepariwisataan yang dimiliki oleh Kabupaten Nias Utara antara lain wisata bahari, wisata alam pegunungan, wisata air terjun, dan juga adat istiadat. Keberadaan obyek wisata itu dimiliki oleh beberapa kecamatan dan layak dijadikan Daerah Tujuan Wisata (DTW) skala nasional maupun internasional.

Sejalan dengan otonomi daerah, pemerintahan kabupaten harus terus menggali, mengemas, membangun dan mempromosikan obyek-obyek wisata yang dimiliki. Namun potensi yang cukup besar ini belum dioptimalkan pengelolaan dan pengembangannya, baik prasarana maupun sarana.

Kecamatan Afulu merupakan salah satu kecamatan yang ada di Kabupaten Nias Utara. Potensi yang dimiliki oleh kecamatan Afulu tidak kalah saing dibandingkan dengan kecamatankecamatan yang lainnya yang ada di Kabupaten Nias Utara. Potensi alam khususnya pada sektor kepariwisataan 
merupakan sektor unggul yang dimiki olah Kecamatan Afulu.

Desa Ombolata Afulu Kecamatan Afulu merupakan salah satu desa yang memiliki potensi alam yang unggul pada sektor pariwisata. Potensi alam yang unggul tersebut tidak didukung oleh pengelolaan prasarana dan sarana secara optimal. Akibatnya obyek wisata yang ada di Desa Ombolata Afulu tersebut masih belum berkembangan dan masih dalam tahap pengembangan. Obyek wisata tersebut adalah obyek wisata Pasir Merah.

Obyek wisata Pasir Merah terletak di Desa Ombolata Afulu Kabupaten Nias Utara. Jarak yang ditempuh untuk mengujungi lokasi obyek wisata ini sekitar 26 km dari lbu Kota Kabupaten Nias Utara atau $80 \mathrm{~km}$ dari Kota Gunungsitoli setara dengan 2,5 jam perjalanan. Obyek wisata Pasir merah ini berhadapan langsung dengan Samudera Hindia. Pantai ini bisa dijangkau dengan kendaraan roda dua atau roda empat. Keistimewaan pantai ini memiliki pasir yang berwarna merah sehingga disebut sebagai "Gawu Soyo" (Pantai Pasir Merah) oleh masyarakat sekitar. Pasir berwarna merah ini hanya membentang sepanjang $3 \mathrm{~km}$ sementara pasir pantai yang lainnya berwarna putih seperti halnya pantai-pantai lain di Pulau Nias.

Obyek wisata Pasir Merah cukup potensial, namun jumlah wisatawan yang berkunjung di obyek wisata Pasir Merah ini mengalami penurunan. Pengunjung pada tahun 2013 berjumlah 150 setiap bulan, pada tahun 2014 berjumlah 135 setiap bulan dan pada tahun 2015 berjumlah 110 setiap bulan (Disparbudpora Nias Utara). Berdasarkan studi observasi penulis di lapangan terlihat bahwa keadaan prasarana dan sarana di lokasi obyek wisata belum dioptimalkan dan memadai, antara lain: belum tersedia pondok bagi pengunjung, belum tersedianya jaringan listrik di lokasi obyek wisata, belum tersedianya pemandu bagi wisatawan serta penerapan sapta pesona yang masih kurang di lokasi obyek wisata. Berdasarkan hal tersebut maka penulis tertarik untuk melakukan penelitian tentang upaya pengembangan obyek wisata Pasir Merah di Desa Ombolata Afulu.

Adapun tujuan penelitian yang diharapkan yaitu (1) Untuk mengetahui keadaan prasarana dan sarana pada obyek wisata Pasir Merah di Desa Ombolata Afulu; (2) Untuk mengetahui penerapan sapta pesona pada obyek wisata Pasir Merah di Desa Ombolata Afulu; (3) Untuk mengetahui upaya yang dilakukan oleh pemerintah daerah dan masyarakat setempat dalam mengembangkan obyek wisata Pasir Merah di Desa Ombolata Afulu.

\section{METODE PENELITIAN}

Penelitian ini berlokasi di objek wisata Pasir Merah Desa Ombolata Afulu, adapun alasan memilih lokasi tersebut sebagai lokasi penelitian, yaitu:

1. Menurunya jumlah wisatawan yang berkunjung pada objek wisata tersebut.

2. Pada lokasi tersebut belum pernah dilakukan penelitian yang serupa.

Populasi dalam penelitian ini adalah seluruh objek wisata Pasir Merah di Desa Ombolata Afulu. Penentuan sampel dalam penelitian ini yaitu total sampling, maka seluruh populasi dijadikan sebagai sampel. Sumber data dalam penelitian ini diperoleh dari masyarakat setempat sebanyak 10 orang dengan asumsi masyarakat yang berada di sekitar obyek wisata, dan 1 orang dari pemerintah daerah. Waktu yang dibutuhkan dalam penelitian ini pada hari biasa mulai pukul 14.00-17.00 WIB dan pada hari minggu pukul 09.00 - 17.00 WIB.

Variabel dalam penelitian ini meliputi keadaan prasarana dan sarana kepariwisataan di objek wisata Pasir Merah Desa Ombolata Afulu, penerapan sapta pesona di objek wisata Pasir Merah Desa Ombolata Afulu dan upaya pengembangan objek wisata Pasir Merah Desa Ombolata Afulu dari pihak pemerintah daerah dan masyarakat setempat. 
Dalam rangka mengumpulkan data yang diperlukan, peneliti menggunakan beberapa teknik dalam mengumpukan data antara lain :

1. Teknik Komunikasi langsung. Alat yang digunakan adalah daftar wawancara yang ditanyakan kepada pemerintahan daerah tentang upaya pengembangan objek wisata Pasir Merah di Desa Ombolata Afulu dan daftar wawancara yang ditanyakan kepada masyarakat sekitar objek wisata tentang dukungan dalam pengembangan objek wisata Pasir Merah di Desa Ombolata Afulu berupa pelayanan jasa bagi wisatawan.

2. Teknik Observasi. Alat yang digunakan adalah lembar observasi dengan melakukan pengamatan langsung ke lokasi penelitian untuk mengetahui secara langsung mengenai keadaan prasarana dan sarana kepariwisataan serta penerapan sapta pesona.

Teknik analisis data yang digunakan adalah deskriptif kualitatif yaitu dengan menganalisis dan mengolah data secara sistematis, kemudian dibantu dengan tabeltabel frekuensi, sehingga dapat memberikan gambaran tentang keadaan objek wisata Pasir Merah di Desa Ombolata Afulu.

Pengelolaan data yang dikualifikasi dilakukan untuk menilai keadaan prasarana dan sarana kepariwisataan serta sapta pesona. Skoring keadaan prasarana, sarana dan sapta pesona kepariwisataan dilakukan secara kualitatif menggunakan skala koordinat 1, 2, dan 3 untuk mengukur kriteria pada masing-masing indikator berkualitas buruk, sedang dan baik. Total skor pengelompokan indikator dimasukkan ke dalam 3 interval kelas, yaitu total skor tertinggi, sedang dan rendah. Mengikuti pedoman Sturges (Budiyono, 1995) dengan rumus:

$$
\mathrm{Ci}=\frac{\text { Range }}{\mathrm{k}}
$$

Dimana:

$$
\begin{array}{ll}
\mathrm{Ci} & =\text { Interval kelas } \\
\text { Range } & =\text { Selisih data terbesar dan terkecil } \\
\mathrm{k} & =\text { Banyak kelas }
\end{array}
$$

\section{HASIL DAN PEMBAHASAN}

Keadaan Prasarana dan sarana kepariwisataan merupakan hal yang harus diperhatikan sehingga kepariwisataan dapat berjalan dengan semestinya. Prasarana dan sarana kepariwisataan merupakan dua aspek yang tidak dapat dipisahkan terutama dalam hal pengembangan objek wisata.

\section{Keadaan Prasarana di Objek Wisata Pasir Merah Desa Ombolata Afulu}

Keadaan prasarana kepariwisataan meliputi jaringan jalan, jaringan listrik, jaringan telekomunikasi, air bersih dan pelayanan kesehatan. Dilihat dari jaringan jalan, Desa Ombolata Afulu memiliki jalan yang sudah diaspal dengan panjang jalan $26 \mathrm{~km}$ dari ibu kota Kabupaten, 6 km dari kantor Camat Afulu dan 0,5 km dari kantor Desa Ombolata Afulu. Jaringan jalan menuju objek wisata Pasir merah ini tergolong baik dan aksesibilitas lancar. Dengan demikian keadaan jaringan jalan di objek wisata Pasir Merah Desa Ombolata Afulu tergolong baik dan berada pada skor 3. Hal ini sesuai dengan yang dikemukakan Yoeti (1996) agar sarana pengangkutan dapat berfungsi, maka diperlukan prasarana perhubungan berupa jalan raya dan jembatan.

Dalam hal jaringan listrik di lokasi objek wisata Pasir Merah masih kurang memadai. Jika dilihat dari waktu pelayanan tenaga listrik yang telah dialirkan oleh pemerintah tidak mencapai 24 jam. Selain itu penerangan jalan pada malam hari di berbagai titik menuju objek wisata ini masih kurang memadai, sehingga terganggunya aktivitas perjalanan bagi transportasi pada malam hari. Untuk itu, keadaan jaringan listrik di objek wisata Pasir Merah Desa Ombolata Afulu tergolong kurang memadai (skor 2). Hal ini serupa dengan yang dikemukakan Suwontoro (2004) bahwa sumber listrik 
dan energi serta jaringan distribusinya yang merupakan bagian vital bagi terselenggaranya penyediaan sarana wisata yang memadai.

Dalam hal jaringan telekomunikasi masih belum tersedia di lokasi objek wisata Pasir Merah. Tower yang merupakan pemancar tidak dapat menjangkau hingga ke desa Ombolata Afulu karena keberadaan tower pemancar jauh dari Desa Ombolata Afulu. Apabila warga desa Ombolata Afulu berkomunikasi melalui Handphone maka harus melakukan perjalanan $\pm 4 \mathrm{~km}$ meninggalkan desa Ombolata tersebut menuju dataran tinggi ataupun mencari lokasi yang terdapat jaringan di desa tengga. Dengan itu maka keadaan jaringan telekomunikasi di objek wisata Pasir Merah Desa Ombolata Afulu tergolong buruk (skor 1). Sejalan dengan yang dikemukakan Yoeti (1996) bahwa wisatawan memerlukan komunikasi dengan orang-orang di negara asalnya atau kontak dengan orang-orang di negara yang dikunjunginya.

Penyediaan air bersih di lokasi objek wisata Pasir Merah sudah memadai. Air bersih yang tersedia merupakan mata air yang mengalir dari kaki gunung. Mata air tersebut ditampung dalam sebuah gudang penampungan oleh warga dan selanjutnya dialirkan untuk kebutuhan masyarakat. Oleh karena itu, keadaan air bersih di objek wisata Pasir Merah Desa Ombolata Afulu tergolong baik (skor 3). Sesuai dengan yang dikemukakan Pangesti (2007) bahwa air bersih merupakan faktor utama dalam pengelolaan dan pelayanan pengunjung. Air tidak harus berasal dalam lokasi tetapi bisa dari luar, seperti adanya PDAM. Unsur-unsur ketersediaan air bersih meliputi volume air, jarak air bersih dari objek wisata, dapat tidaknya air dialirkan ke objek wisata, kelayakan dikonsumsi, ketersediaan.

Dalam hal pelayanan kesehatan merupakan kebutuhan manusia ketika terjadi gangguan yang memberikan ketidak nyamanan pada diri. Di desa Ombolata afulu keadaan Pelayanan kesehatan tidak memadai. Untuk mengobati berbagai penyakit ringan yang diderita oleh warga maka dapat membeli obat-obat yang dijual bebas di warung-warung milik warga. Untuk pasien yang memiliki penyakit yang tidak dapat diatasi secara sederhana maka dapat dikirimkan ke rumah sakit umum yang ada di Kecamatan Lahewa yang berjarak $\pm 15 \mathrm{~km}$ dari desa Ombolata Afulu. Keadaan itu menunjukan Pelayanan kesehatan di objek wisata Pasir Merah Desa Ombolata Afulu tergolong kurang memadai dengan (skor 2). Hal ini sesuai dengan yang dikemukakan Yoeti (1996) bahwa dalam sebuah perjalanan wisata arus ada jaminan bahwa di daerah tujuan wisata tersedia pelayanan bagi suatu penyakit yang mungkin akan diderita dalam perjalanan.

Secara keseluruhan kondisi prasarana kepariwisataan di objek wisata Pasir Merah di Desa Ombolata Afulu yang meliputi jaringan jalan, jaringan listrik, jaringan telekomunikasi, air bersih dan pelayanan kesehatan tergolong sedang dengan skor rata-rata 2,2. Hal ini sesuai dengan yang dikatakan oleh Yoeti (1996) Prasarana Wisata adalah semua fasilitas yang dapat memungkinkan proses perekonomian berjalan dengan lancar sedemikian rupa, sehingga dapat memudahkan manusia untuk dapat memenuhi kebutuhannya. Berdasarkan hal itu maka keadaan prasarana harus baik agar perjalanan wisata berjalan dengan lancar serta terpenuhi keinginan para pengunjung yang berwisata.

\section{Keadaan Sarana di Objek Wisata Pasir Merah Desa Ombolata Afulu}

Keadaan sarana kepariwisataan meliputi transportasi, rumah makan, pondok pengunjung, penyediaan souvenir, tempat penginapan, promosi, obyek/atraksi wisata, pemandu wisata, tempat sampah, toilet dan tempat parkir. Ditinjau dari transportasi di objek wisata Pasir Merah Desa Ombolata Afulu, angkutan umum sudah ada namun terbatas dengan jumlah 2 unit namun tidak berjalan 
dengan lancar. Pengunjung biasanya datang ke objek wisata ini mayoritas menggunakan kendaraan pribadi seperti mobil pribadi dan sepeda motor, selain itu juga pengunjung biasanya menggunakan travel atau sejenis mobil pribadi yang disewa. Tarif penumpang dari lbu Kota Nias Utara sampai ke lokasi objek wisata Rp 45.000/orang untuk angkutan umum. Dengan demikian, keadaan transportasi di objek wisata Pasir Merah Desa Ombolata Afulu tergolong dalam kategori sedang dengan skor 2. Hal ini sesuai dengan yang dikemukakan Yoeti (1996) bahwa aksesbilitas merupakan unsur yang sangat penting dalam pariwisata. aksesbilitas ditentukan oleh kondisi jalan, kualitas jalan, jumlah angkutan, jarak objek dengan pusat kota, juga terdapat prasarana seperti jaringan telekomunikasi, jaringan listrik, fasilitas kesehatan dan jumlah kantor pos.

Ditinjau dari keadaan rumah makan di objek wisata Pasir Merah Desa Ombolata Afulu belum tersedia dekat dengan objek wisata. Rumah makan terdekat di obyek wisata ini berada pada jarak yang jauh yaitu $5 \mathrm{~km}$ dari objek wisata menuju kota kecamatan Afulu dengan waktu tempuh 15-20 menit perjalanan. Dengan jarak tersebut maka membutuhkan waktu yang lama bagi pengunjung. Oleh karena itu, keadaan rumah makan di objek wisata Pasir Merah Desa Ombolata Afulu tergolong dalam kategori sedang dengan skor 2 .

Dalam hal keadaan pondok pengunjung di objek wisata Pasir Merah Desa Ombolata Afulu belum tersedia. Terdapat sebuah pondok yang tidak lagi layak pakai. Pondok tersebut merupakan sisa pondok yang masih belum hancur. Pada tahun-tahun sebelumnya terdapat \pm 15 unit pondok namun telah hancur karena tidak difungsikan seiring dengan semakin berkurangnya pengunjung di lokasi objek wisata Pasir Merah. Keadaan tersebut menjadikan pondok pengunjung di objek wisata Pasir Merah Desa Ombolata Afulu tergolong dalam kategori buruk dengan skor 1 .

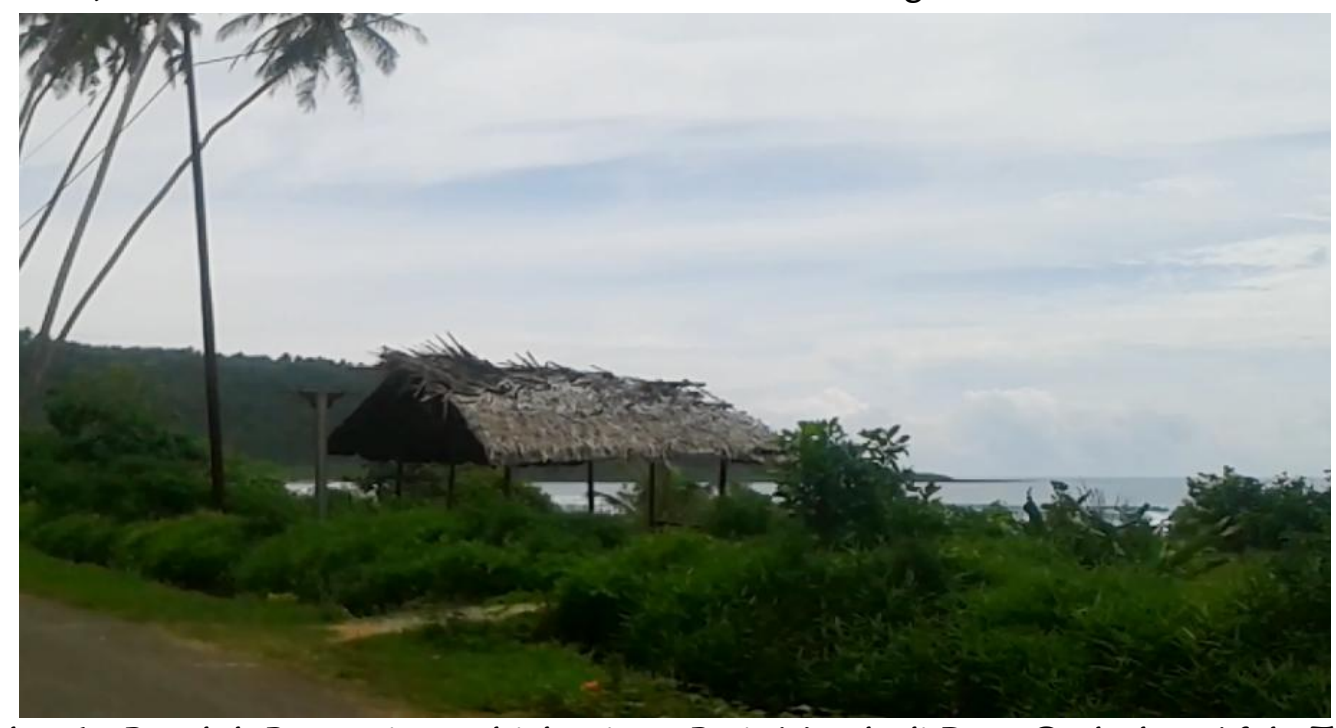

Gambar 1. Pondok Pengunjung objek wisata Pasir Merah di Desa Ombolata Afulu Tahun 2016.

Begitu halnya dengan penyediaan souvenir di objek wisata Pasir Merah Desa Ombolata Afulu belum tersedia. Keberadaan toko souvenir memiliki jarak $\pm 15 \mathrm{~km}$ dari lokasi objek wisata yaitu di Kecamatan Lahewa. Toko souvenir tersebut tidak menampilkan ciri khas daerah lokasi objek wisata Pasir Merah. Dengan demikian, penyediaan souvenir di objek wisata Pasir Merah Desa Ombolata Afulu tergolong dalam kategori buruk dengan skor 1.

Ditinjau dari ketersediaan tempat penginapan tidak jauh berbeda dengan 
keberadaan tempat souvenir. Tempat penginapan terdekat terdapat di kota kecamatan Afulu dengan jarak $\pm 6 \mathrm{~km}$ perjalanan dan ada juga di kota Kecamatan Lahewa yang berjarak $\pm 15 \mathrm{~km}$ dari objek wisata. Namun demikian dapat dijangkau oleh pengunjung yang ingin menginap. Oleh karena itu tempat penginapan di objek wisata Pasir Merah Desa Ombolata Afulu tergolong dalam kategori baik dengan skor 3. Hal ini sesuai dengan yang dikemukakan Yoeti (1996) bahwa tempattempat yang menyediakan fasilitas untuk rekreasi yang fungsinya tidak hanya melengkapi sarana pokok kepariwisataan, tetapi yang terpenting adalah untuk membuat agar para wisatawan dapat lebih lama tinggal pada suatu daerah tujuan wisata.

Dalam hal promosi objek wisata Pasir Merah Desa Ombolata Afulu pelaksanannya masih di dalam daerah saja. Promosi ini pelaksanaannya terbatas yang dilakukan melalui spanduk, booklet dan internet yang dimuat dalam website. Keadaan tersebut menjadikan promosi di objek wisata Pasir Merah Desa Ombolata Afulu tergolong dalam kategori sedang dengan skor 2. Hal ini sesuai dengan yang dikemukakan Yoeti (1996) bahwa promosi yang dilakukan hendak mencapai sasaran agar lebih banyak wisatawan yang datang pada suatu daerah, lebih lama tinggal dan lebih banyak mengeluarkan uangnya di tempat yang mereka kunjungi.

Objek/atraksi wisata di objek wisata Pasir Merah Desa Ombolata Afulu ini masih belum ada. Atraksi wisata belum ada disebabkan karena pengunjung yang sedikit sehingga tidak ada suatu persiapan untuk menunjukan atraksi. Sumber daya manusia dalam menunjukkan suatu atraksi masih kurang. Maka dengan itu, objek/atraksi wisata di objek wisata Pasir Merah Desa Ombolata Afulu tergolong dalam kategori buruk dengan skor 1 . Sejalan dengan yang dkemukakan Yoeti (1996) atraksi wisata merupakan sesuatu yang dipersiapkan terlebih dahulu agar dapat dilihat, dinikmati dan yang termasuk dalam hal ini: tari-tarian, nyanyian, kesenian rakyat tradisional, upacara adat, dan lain-lain.

Dilihat dari keadaan pemandu wisata di objek wisata Pasir Merah Desa Ombolata Afulu belum tersedia. Pengunjung yang melakukan kegiatan wisata di objek wisata merasa kurang nyaman dan khawatir akan terjadi sesuatu yang mencelakakan. Pemandu wisata merupakan roda dalam perjalanan wisata agar perjalanan aman dan tidak ada yang dikhawatirkan. Dengan demikian, keadaan pemandu wisata di objek wisata Pasir Merah Desa Ombolata Afulu tergolong dalam kategori buruk dengan skor 1 .

Dalam hal ketersediaan tempat sampah di lokasi objek wisata Pasir Merah Desa Ombolata Afulu masih belum tersedia. Lokasi objek wisata terilihat kotor dengan sampah yang berserakan. Hal ini disebabkan karena masih kurangnya kesadaran masyarakat/pengelola untuk menyediakan tempat sampah. Dengan itu, keadaan tempat sampah di objek wisata Pasir Merah Desa Ombolata Afulu tergolong buruk dengan skor 1 .

Begitu halnya dengan keadaan toilet di lokasi objek wisata Pasir Merah Desa Ombolata Afulu masih belum tersedia. Apabila pengunjung ingin mengganti pakaian atau pun membuang air kecil/besar maka harus menumpang di rumah warga sekitar objek wisata. Keadaan tersebut menjadikan toilet di objek wisata Pasir Merah Desa Ombolata Afulu tergolong dalam kategori buruk dengan skor 1.

Ditinjau keadaan tempat parkir di lokasi objek wisata Pasir Merah Desa Ombolata Afulu masih belum tersedia. Tempat parkir di lokasi objek wisata sementara menggunakan halaman rumah para warga. Tidak ada patokan biaya untuk parkiran tersebut namun kesadaran para pengendara untuk mengucapkan terimaksih kepada pemilik rumah. Keadaan tersebut menjadikan tempat parkir di lokasi objek wisata Pasir Merah Desa Ombolata Afulu tergolong buruk denga skor 1 . 
Secara keseluruhan keadaan sarana pariwisata di objek wisata Pasir Merah Desa Ombolata Afulu meliputi transportasi, rumah makan, pondok pengunjung, penyediaan souvenir, tempat penginapan, promosi, obyek/atraksi wisata, pemandu wisata, tempat sampah, toilet dan tempat parkir tergolong dalam kategori buruk dengan skor rata-rata 1,45. Hal ini sesuai dengan yang dikemukakan Yoeti (1996) yakni kondisi sarana kepariwisataan dikatakan baik apabila terdapat sarana transportasi umum, rumah makan dan penginapan, pondok pengunjung, penyediaan souvenir sebagai kenang-kanangan bagi pengunjung, atraksi wisata, pemandu wisata, tempat sampah, toilet, tempat parkir dan promosi yang menarik banyak perhatian pengunjung untuk berwisata. Penyediaan sarana wisata juga penting sehingga para pengunjung tinggal memilih atau menentukan jenis dan kualitas yang digunakan.

\section{Keadaan Sapta Pesona Kepariwisataan di Objek Wisata Pasir Merah}

Sapta pesona yang dimaksud dalam penelitian ini adalah keamanan, ketertiban, kebersihan, kesejukan, keindahan, ramah tamah dan kenangan. Dalam hal keamanan, objek wisata Pasir Merah di Desa Ombolata Afulu tergolong dalam kategori tidak aman. Pernah terjadi perkelahian antar warga desa lain yang mengunjungi objek wisata ini. Selain itu, warga juga mengata bahwa pernah tenggelamnya salah seorang pengunjung yang hendak berenang. Hal ini menunjukan bahwa penerapan keamanan di objek wisata Pasir Merah Desa Ombolata Afulu tergolong dalam kategori buruk dengan skor 1 .

Dilihat dari aspek ketertiban, objek wisata Pasir Merah di Desa Ombolata Afulu masih belum tertib. Pada objek wisata Pasir Merah ini terlihat tidak tertata dengan rapi dan sepanjang pantai tidak teratur. Keadaan tersebut menunjukan bahwa penerapan ketertiban di objek wisata Pasir Merah Desa Ombolata Afulu tergolong dalam kategori buruk dengan skor 1.

Dalam hal kebersihan, objek wisata Pasir Merah di Desa Ombolata Afulu masih belum bersih, masih ada sampah bertebaran di sepanjang pantai yang merupakan lokasi objek wisata. Sampahsampah tersebut merupakan sampah dari pengunjung maupun ranting-ranting pohon yang terbawa oleh arus ombak. Hal ini menunjukan bahwa penerapan kebersihan di objek wisata Pasir Merah Desa Ombolata Afulu tergolong dalam kategori sedang dengan skor 2 .

Dilihat dari aspek kesejukan, objek wisata Pasir Merah di Desa Ombolata Afulu tergolong sejuk dengan pepohonan yang berada disekitar pinggiran pantai. Pepohonan tersebut didominasi oleh kelapa, sehingga masyarat disekitar objek wisata tetap melestarikan pepohonan tersebut. dengan demikian, kesejukan di objek wisata Pasir Merah Desa Ombolata Afulu tergolong baik dengan skor 3 .

Ditinjau dari aspek keindahan, objek wisata Pasir Merah di Desa Ombolata Afulu masih kurang indah. Lokasi objek wisata belum tertata rapi dan segala rerumputan masih berserakan di sembarang tempat. Namun demikian hal keindahan dapat terlihat di sisi lain seperti halnya ombak yang deras yang tidak berhenti. Hal tersebut menjadikan keindahan di objek wisata Pasir Merah Desa Ombolata Afulu tergolong sedang dengan skor 2. Dalam hal keramahtamahan di lokasi objek wisata Pasir Merah, pengunjung merasakan suasana yang hangat dari masyarakat sekitar lokasi objek wisata. Namun, ditinjau penerapan keramah-tamahan di objek wisata Pasir Merah Desa Ombolata Afulu tergolong baik dengan skor 3 . 


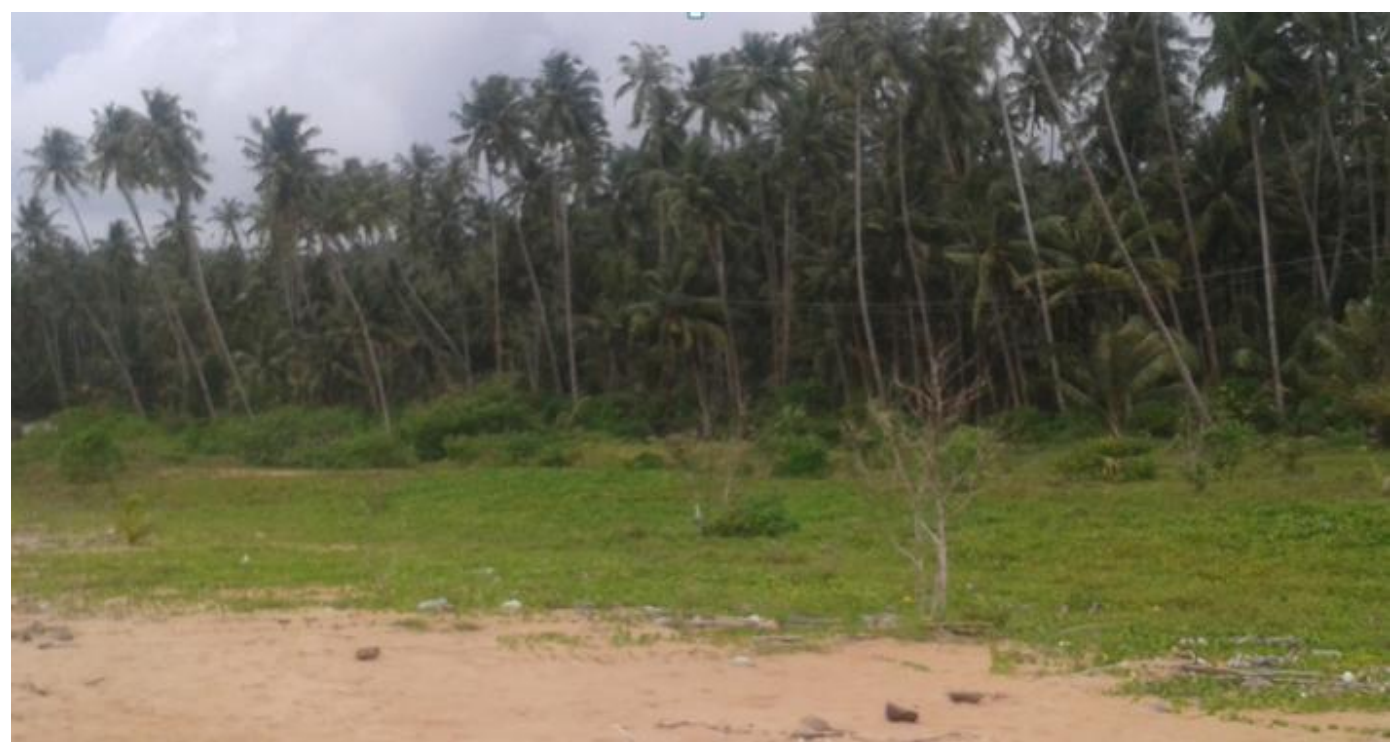

Gambar 2. Keadaan Pepohonan yang Berjejeran Sekitar Objek Wisata Pasir Merah di Desa Ombolata Afulu Tahun 2016

Demikian halnya dengan kenangan di objek wisata Pasir Merah Desa Ombolata Afulu, bahwa masih kurangnya kenangan yang dirasakan oleh pengunjung. Toko souvenir atau pun penjualan souvenir masih belum ada di lokasi objek wisata ini. Namun demikian, dengan kelangkaan pantai ini yang memiliki pasir berwarna merah maka memberikan kesan yang tidak terlupakan. Hal ini menunjukan bahwa kenangan di objek wisata Pasir Merah Desa Ombolata Afulu tergolong sedang dengan skor 2 .

Secara keseluruhan, penerapan sapta pesona yang meliputi keamanan, ketertiban, kebersihan, kesejukan, keindahan, ramah tamah dan kenangan di objek wisata Pasir Merah Desa Ombolata Afulu tergolong dalam kategori sedang dengan skor rata-rata 2,0. Hal ini juga sesuai dengan yang dikemukakan Sowantoro (2004) bahwa daya tarik wisata alam dan situs budaya ditentukan oleh keaslian, keindahan, keunikan, kekhasan, dan pemeliharaan objek wisata dan sikap masyarakat sehingga objek wisata itu sangat menarik bagi wisatawan serta sulit dijumpai ditempat lain.

Upaya Pemerintah Daerah dan Masyarakat Setempat dalam Mengembangkan Objek
Wisata Pasir Merah di Desa Ombolata Afulu Kabupaten Nias Utara

Dalam upaya pengembangan objek

Wisata Pasir Merah di Desa Ombolata Afulu Kabupaten Nias Utara tidak terlepas dari kerjasama antara pemerintahan dan masyarakat. Ditinjau dari upaya pengembangan objek wisata Pasir Merah dari pihak pemerintah daerah bahwa pada tahun 2017 mendatang akan dibangun pondok-pondok bagi pengunjung. Pengembangan akan dilakukan secara bertahap dikarenakan alokasi dana yang juga terbatas. Adapun program lain yang selalu rutin dilaksanakan tiap tahunnya yaitu membentuk kelompok sadar wisata (Darwis) pada setiap objek wisata yang ada di Kabupaten Nias Utara. Tujuannya agar kesadaran masyarakat akan pentingnya pemeliharaan, pengembangan objek wisata yang dapat memberikan manfaat bagi perekonomian maupun pendidikan. Sesuai dengan yang dikemukakan oleh Suwontoro (2004) bahwa pemerintah bertanggung jawab atas empat hal utama yaitu: perencanaan (planning) daerah atau kawasan pariwisata, pembangunan (development) fasilitas utama dan pendukung pariwisata, pengeluaran kebijakan (policy) pariwisata, 
dan pembuatan dan penegakan peraturan (regulation).

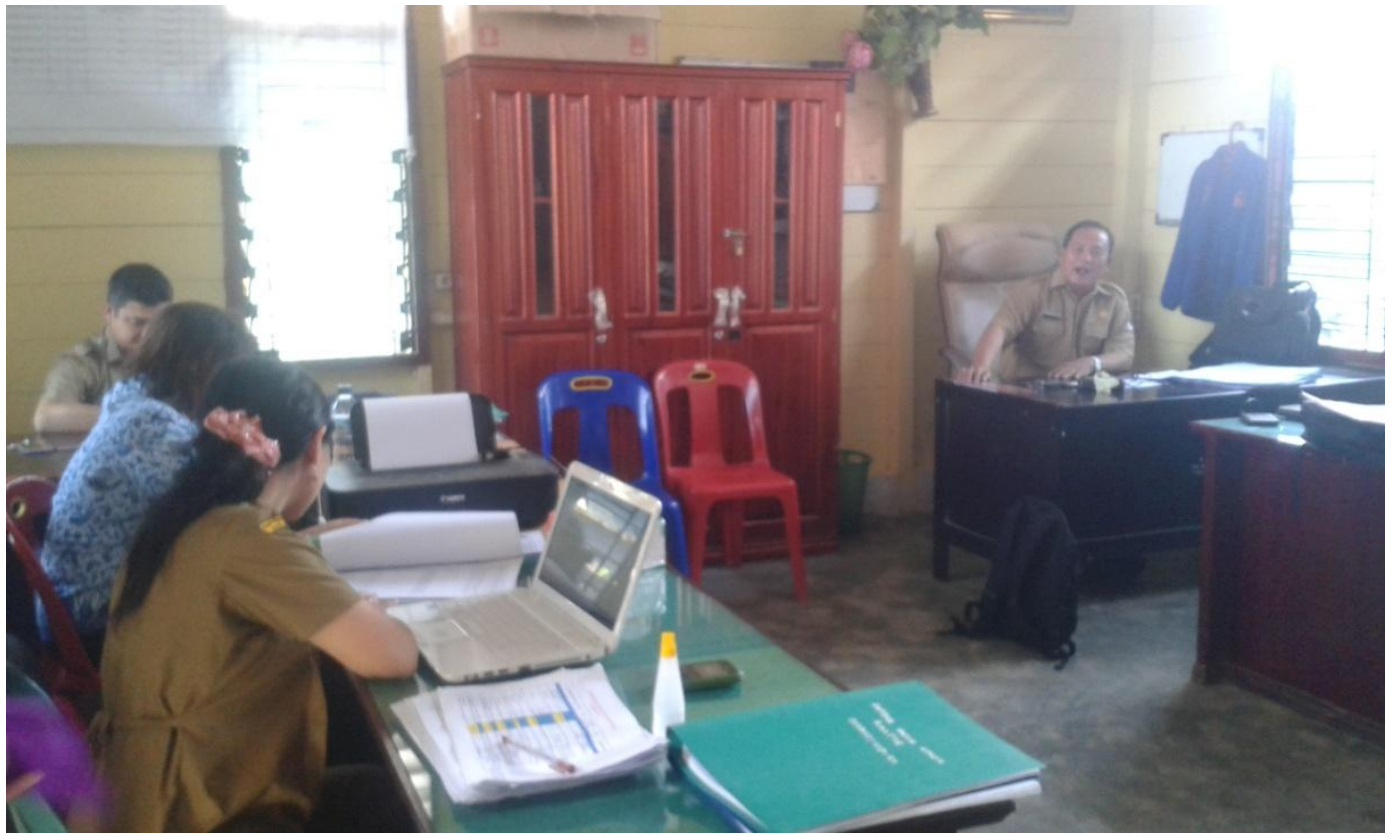

Gambar 3. Keadaan Kantor Disbudparpora Bidang Kepariwisataan Kabupaten Nias Utara Tahun 2016

Dalam pengembangan objek wisata Pasir Merah di Desa Ombolata Afulu juga mengalami beberapa kendala yang menjadikan proses pengembangan tidak berjalan sesuai harapan, hal ini disebabkan masih kurangnya sumber daya manusia (SDM) yang menjadi salah satu faktor berkembangnya suatu objek wisata. SDM yang dimaksud adalah pihak pengelola mapun pihak masyarakat sekitar objek wisata. Sesuai yang dikemukakan Evans (2003) bahwa SDM di sektor pariwisata merupakan sumber daya yang sangat penting di sebagian besar organisasi. Khususnya di organisasi berbasis jasa (service-based organization), SDM berperan sebagai faktor kunci dalam mewujudkan keberhasilan kinerja. Selanjutnya diuraikan bahwa pada beberapa industri, faktor manusia berperan penting dan menjadi faktor kunci sukses terhadap pencapaian kinerja. Seperti pada industri pariwisata, dimana perusahaan memiliki hubungan langsung yang bersifat intangible (tak berwujud) dengan konsumen yang sangat bergantung pada kemampuan individu karyawan dalam membangkitkan minat dan menciptakan kesenangan serta kenyaman kepada para konsumennya.

Sejalan dengan upaya pemerintah, masyarakat dalam hal ini warga Desa Ombolata Afulu yang berdomisili disekitar lokasi objek wisata begitu antusias untuk berkembangnya kembali objek wisata Pasir Merah. Objek wisata Pasir Merah memberikan banyak manfaat bagi manyarakat setempat menambah perekonomian masyarakat. Selain itu juga dengan datangnya pengunjung dari luar daerah memberikan pengetahuan baru seperti kemampuan dalam berbahasa asing. Selain itu juga kerja nyata dari masyarakat sekitar objek wisata berupaya membangun penginapan serta rumah makan sehingga pengunjung tertarik untuk datang berwisata. Hal ini sesuai dengan yang dikemukakan oleh Suwontoro (2004) bahwa Partisipasi aktif dapat dilaksanakan secara langsung baik secara perorangan maupun secara bersama-sama yang secara sadar ikut membantu program pemerintah dengan inisiatif dan reaksi mau melibatkan diri dalam kegiatan pengusahaan atau melalui pembinaan rasa memiliki dari kalangan masyarakat. Sedangkan Partisipasi 
pasif adalah timbulnya kesadaran untuk tidak melakukan kegiatan-kegiatan yang dapat mengganggu atau merusak lingkungan alam. Upaya peningkatan peran serta pasif dapat dilakukan melalui penyuluhan maupun dialog dengan aparat pemerintah, penyebaran informasi mengenai pentingnya upaya pelestarian sumber daya alam disekitar kawasan objek wisata, seperti jasa penginapan, penyediaan warung makan, toko souvenir, pemandu atau penunjuk arah, photografi dan menjadi pegawai pengusahaan pariwisata.

\section{KESIMPULAN DAN SARAN Kesimpulan}

Berdasarkan pembahasan dalam penelitian ini maka diperoleh kesimpulan bahwa:

1. Keadaan prasarana kepariwisataan di objek wisata Pasir Merah di Desa Ombolata Afulu yang meliputi jaringan jalan, jaringan listrik, air bersih, jaringan telekomunikasi, dan jaringan kesehatan tergolong sedang dengan skor rata-rata 2,2. Keadaan sarana pariwisata di objek wisata Pasir Merah Desa Ombolata Afulu meliputi transportasi, rumah makan, pondok pengunjung, penyediaan souvenir, tempat penginapan, promosi, obyek/atraksi wisata, pemandu wisata, tempat sampah, toilet dan tempat parkir tergolong dalam kategori buruk dengan skor rata-rata 1,45.

2. Penerapan sapta pesona di objek wisata Pasir Merah di Desa Ombolata Afulu yang meliputi keamanan, ketertiban, kebersihan, kesejukan, keindahan, ramah tamah dan kenangan tergolong sedang dengan skor rata-rata 2,0. Keberadaan keamanan serta ketertiban di lokasi objek wisata masih kurang baik.

3. Upaya pengembangan objek wisata Pasir Merah di Desa Ombolata Afulu dari pihak pemerintah daerah bahwa pada tahun 2017 mendatang akan dibangun pondok-pondok bagi pengunjung. Selain itu, menjalankan rutin kegiatan kelompok sadar wisata yang dibentuk oleh pemerintah daerah Kabupaten Nias Utara. Tujuannya agar kesadaran masyarakat akan pentingnya pemeliharaan, pengembangan objek wisata yang dapat memberikan manfaat bagi perekonomian maupun pendidikan. Upaya pengembangan objek wisata Pasir Merah di Desa Ombala Afulu dari pihak masyarakat bahwa masyarakat mendukung penuh kegiatan pemerintah dalam pengembangan objek wisata ini. selain itu, sebagai wujud nyata dalam upaya pengembangan objek wisata ini maka masyarakat membangun penginapan dan rumah makan sehingga pengunjung tertarik untuk datang berwisata.

\section{Saran}

Sesuai kesimpulan penelitian, maka saran yang dapat diajukan penulis antara lain:

1. Ditinjau dari keadaan objek wisata Pasir Merah Desa Ombolata Afulu dengan prasarana yang kurang baik maka perlu penyediaan jaringan telekomunikasi. Untuk keadaan sarana pariwisata yang buruk maka perlu penyediaan obyek/atraksi wisata, pembangunan toko-toko souvenir, kegiatan promosi di luar daerah, penyediaan pemandu wisata, pembangunan toilet dan penyediaan tempat sampah di lokasi obyek wisata. Hal ini agar daerah tujuan wisata nyaman dan menarik banyak pengunjung.

2. Dicermati dari keadaan sapta pesona yang masih kurang pada objek wisata Pasir Merah Desa Ombolata Afulu, maka perlu ditingkatkan penerapannya terutama pada keamanan lokasi objek wisata dengan menyediakan penjaga keamanan baik dari masyarakat lokal maupun dari 
pihak pemerintah agar kegiatan wisatawan berjalan lancar.

3. Pengembangan objek wisata Pasir Merah Kurang berhasil sehingga terdapat kelemahan di berbagai komponen baik dari pihak pemerintah maupun dari pihak masyarakat setempat. Dalam hal ini pemerintah daerah melalui Dinas Kebudayaan Pariwisata Pemuda dan Olahraga (Disbudparpora) Kabupaten Nias Utara membangun jaringan telekomunikasi sehingga menjangkau objek wisata, penyediaan obyek/atraksi wisata, toko souvenir, penguatan kegiatan promosi di luar daerah, penyediaan pemandu wisata, pembangunan toilet dan penyediaan tempat sampah di lokasi obyek wisata. Selain itu, dalam upaya pengembangan objek wisata Pasir Merah kiranya terjalin kerjasama yang baik antara pihak pemerintah daerah dengan masyarakat setempat.

\section{DAFTAR PUSTAKA}

Dwiyana, K. 2014. Potensi Obyek Wisata Danau Buatan Padangri Kecamatan Kotapinang Kabupaten Labuhanbatu Selatan. Skripsi. Medan: Jurusan Pendidikan Geografi Fakultas IImu Sosial Universitas Negeri Medan.

Damanik, J. dan Weber, H..2006.Perencanaan Ekowisata Dari Teori ke Aplikasi. Yogyakarta: Andi.

Evans, dkk. 2003. Strategic Management for Travel and Tourism. Oxford: Butterworth-Heinemann.

Harefa, L. M. Sari. 2013. Studi Potensi Objek Wisata di Kecamatan Sirombu Kabupaten Nias Barat. Skripsi. Medan: Jurusan Pendidikan Geografi Fakultas Ilmu Sosial Universitas Negeri Medan.

Lumban Batu, J.. 2016. Faktor-faktor yang Menyebabkan Menurunnya Jumlah Pengunjung di Objek Wisata Kecamatan Baktiraja Kabupaten
Humbang Hasundutan. Skripsi. Medan: Jurusan Pendidikan Geografi Fakultas Ilmu Sosial Universitas Negeri Medan.

Marpaung, dkk. 2002. Pengantar Pariwisata. Bandung: CV. Alfabeta.

Muljadi, A.J..2012. Kepariwisataan dan Perjalanan. Jakarta: PT Raja Grafindo Persada.

Pangesti, MH. T. 2007. Modul Praktek Objek Wisata Alam. Balai Diklat Kehutanan Bogor, Bogor.

Pendit, Nyoman S.. 2006. Ilmu Pariwisata, Sebuah Pengantar Perdana. Jakarta: Pradny Paramita.

. 2002. Ilmu Pariwisata. Jakarta: Pradny Paramita.

Peraturan Pemerintah Republik Indonesia Nomor 50 Tahun 2011 Tentang Rencana Induk Pembangunan Kepariwisataan Tahun 2010-2025.

Pinem, M., \& Natalia, I. (2017). PERSEBARAN DAN POTENSI OBJEK WISATA DI KOTA MEDAN. JURNAL GEOGRAFI, 1(1), 57-64.

Rangkuty, L. Hayati. 2013. Keadaan Objek Wisata Alam Pandayangan Indah di Desa Ulumahuam Kecamatan Silangkitang Kabupaten Labuhan Batu

Selatan. Skripsi. Medan: Jurusan Pendidikan Geografi Fakultas Ilmu Sosial Universitas Negeri Medan.

Sipayung, Dimpley. 2015. Kondisi Objek Wisata di Kecamatan Dolok Perdamean Kabupaten Simalungun. Skripsi. Medan: Jurusan Pendidikan Geografi Fakultas Ilmu Sosial Universitas Negeri Medan.

Siregar, S., \& Pinem, M. (2012). Potensi Objek Wisata Kabupaten Dairi. JURNAL GEOGRAFI, 4(1), 67-79. 
Surat Keputusan (SK) Nomor 556/219/K/Tahun 2013 Tentang Penetapan Lokasi Objek Wisata dan Rekreasi di Kabupaten Nias Utara.

Suwantoro, Gamal. 2004. Dasar-dasar Pariwisata. Yogyakarta: ANDI.

Suwena, I Ketut, dkk. 2010. Pengetahuan Dasar Ilmu Pariwisata. Bali: Udayana University Pres.

Tim Peneliti PMB-LIPI. 2006. Sarana dan Prasarana

Pariwisata.http://file.upi.edu/Direktori /FPIPS/JUR._PEND._GEOGRAFI/19721 0242001121-

BAGJA_WALUYA/GEOGRAFI_PARIWI
SATA/Kriteria_Prasarana_dan_Sarana Pariwisata.pdf.Diakses pada tanggal $\overline{12}$ Mei 2016.

Undang Undang Republik Indonesia Nomor 10 Tahun 2009 tentang Kepariwisataan di Indonesia.

UndangUndang Republik Indonesia, Nomor 45 Tahun 2008 Tentang Pembentukan Kabupaten Nias Utara di Provinsi Sumatera Utara.

Wahab, Salah. 2003. Manajemen Kepariwisataan. Jakarta: Prandya Paramita.

Yoeti, Oka A. 1996. Pengantar Ilmu Pariwisata.Bandung: Angkasa. 